\title{
ANALISIS PENANGKAPAN IKAN KAKAP MERAH (Lutjanus spp.) DAN KERAPU (Epinephelus sp.) DI PERAIRAN BARRU, SULAWESI SELATAN
}

\author{
Bambang Sumiono, Tri Ernawati, dan Wedjatmiko \\ Peneliti pada Balai Riset Perikanan Laut, Muara Baru-Jakarta \\ Teregistrasi I tanggal: 8 Oktober 2009; Diterima setelah perbaikan tanggal: 19 Oktober 2010; \\ Disetujui terbit tanggal: 29 Oktober 2010
}

\begin{abstract}
ABSTRAK
Perairan di sekitar Barru Sulawesi Selatan merupakan salah satu kawasan terumbu karang yang penting di Selat Makassar. Sebagian besar dari nelayannya melakukan penangkapan ikan dengan menggunakan rawai dasar dan jaring insang dasar. Analisis perikanan ikan kakap merah (Lutjanus spp.) dan kerapu (Epinephelus sp.) dilakukan pada bulan Agustus dan Oktober 2006 dengan penekanan pada deskripsi alat tangkap dan teknik penangkapannya, komposisi hasil tangkapan, dan beberapa aspek biologi ikan kakap merah dan kerapu. Penelitian ini dilakukan dengan cara mengikuti kegiatan nelayan yang menggunakan rawai dasar dan jaring insang dasar di sekitar terumbu karang dan pencatatan data dari pendaratan ikan utama. Untuk kelengkapan data dilakukan wawancara dengan nelayan dan pedagang pengumpul setempat. Hasil penelitian ini menunjukan daerah penyebaran ikan kakap merah dan kerapu terdapat di perairan Barru dan Pangkajene Kepulauan. Pada perairan yang relatif dangkal $(<50 \mathrm{~m}$ ) digunakan pancing ulur dengan satu atau dua mata pancing (nomor 6 atau 7). Jaring insang dasar digunakan di luar daerah karang, satu pis (tinting) mempunyai panjang $40 \mathrm{~m}$ dan dalam $5 \mathrm{~m}$ dengan ukuran mata jaring 4 inci. Satu unit jaring terdiri atas 60 pis. Di perairan yang lebih dalam (lebih dari 50) digunakan rawai dasar yang terdiri atas 600 mata pancing (nomor 7 atau 8). Lama trip penangkapan tiga hari. Diperoleh laju pancing pada rawai dasar berkisar 6-8\% dan laju tangkap jaring insang dasar berkisar antara 40-60 $\mathrm{kg} / \mathrm{kapal} /$ tiga hari. Komposisi hasil tangkapan didominansi $(47,2 \%)$ oleh ikan kakap merah (famili Lutjanidae) yang terdiri atas jenis Lutjanus malabaricus, Lutjanus hyselopterus, Lutjanus sebae, Lutjanus vittus, dan Pinjalo pinjalo. Ikan kerapu (famili Serranidae) terdiri atas jenis Epinephelus areolatus, Epinephelus malabaricus, Epinephelus microdon, dan Plectropomus maculatus. Kecuali itu tertangkap juga ikan lencam (famili Lethrinidae). Pengamatan biologi jenis ikan Lutjanus malabaricus dan Epinephelus malabaricus yang merupakan hasil tangkapan dominan masing-masing diperoleh nilai modus panjang cagak 48 dan $56 \mathrm{~cm}$ dengan modus bobot masing-masing 1,8 dan 2,15 kg. Karakteristik pertumbuhan kedua jenis tersebut adalah allometrik positif.
\end{abstract}

KATA KUNCl: ikan kakap merah, ikan kerapu, Barru, Sulawesi Selatan 


\begin{abstract}
Analysis of snappers (Lutjanus spp.) and groupers (Epinephelus sp.) fisheries in the waters of Barru, South Sulawesi. By: Bambang Sumiono, Tri Ernawati, and Wedjatmiko
\end{abstract}

\begin{abstract}
The sea waters around Barru, South Sulawesi is one of the coral reef parts in Makassar Strait. Most of the fishermen use fishing lines, bottom long lines, and bottom gill nets in their fishing activities. Analysis of red snappers (Lutjanus spp.) and groupers (Epinephelus sp.) fisheries in this area were carried out in August and October, 2006. The emphasis is focused on the discription of fishing gear and fishing technique, catch composition, and some of biological aspect of red snappers and groupers. The research was done by following the fishing operations of bottom long line and bottom gill net conducted by fishers in the waters around coral reefs. Data were recorded in some importantant landing place at Barru, and interview of some fishermen to complete data and information needed. The result showed that the distribution of red snapper and groupers occured in the waters around Barru and Pangkajene Islands. In the shallow waters $(<50 \mathrm{~m})$ the fishermen use a lightly weighted hand line, with one or two relativelly small hooks (nomor 6 or 7). Bottom gill nets are frequently used in shallow back reef areas with one piece of $40 \mathrm{~m}$ in length, and $5 \mathrm{~m}$ in depth, with mesh size of 4 inches. One unit of the gear consisted of 60 piece of the nets. Meanwhile, in deeper waters (50-150 m), the number of hooks (nomor 7 or 8) in bottom long line operated 600 hooks for each unit. All fishing gears usually have three days at sea for a fishing trip. The average of catch rate (hook rate) for a trip of bottom long line was 6-8\% (6 or 8 individual fish for 100 hooks). Meanwhile, the catch rate of bottom jaring insang was about 40-60 kgs/boat/3 days trip. The catches were dominated by the family Lutjanidae in which the red snappers species (reached to $47.2 \%$ at this survey period) including Lutjanus malabaricus, Lutjanus hyselopterus, Lutjanus sebae, Lutjanus vittus, and Pinjalo pinjalo. Meanwhile the groupers (family Serranidae) were dominated by species of Epinephelus areolatus, Epinephelus malabaricus, Epinephelus microdon, and Plectropomus maculatus. Other groups were emperors (Lethrinidae) and Gymnocranius. The biological measured for Lutjanus malabaricus and Epinephelus malabaricus as a dominant landed showed the modus of length were 48 and $58 \mathrm{cmFL}$, respectivelly. Meanwhile the modus of weight were 1.8 and $2.35 \mathrm{~kg}$. The growth characteristic of both species were positive allometric. It means that increasing the weight was faster than their length.
\end{abstract}

\title{
KEYWORDS: $\quad$ red snapper, grouper, Barru, South Sulawesi
}

\section{PENDAHULUAN}

Penyediaan data dan informasi terbaru memegang peranan penting dalam pengembangan dan pengelolaan sumber daya ikan di suatu wilayah perairan, yaitu untuk menjamin tujuan hasil tangkapan yang optimal secara berkesinambungan dalam jangka panjang. Salah satu daerah yang belum banyak dilakukan penelitian terhadap perikanan demersal adalah perairan Kabupaten Barru, Sulawesi Selatan yang merupakan bagian dari Selat Makassar. Menurut Saouma (1986) untuk mencapai tujuan pengelolaan sumber daya perikanan di suatu perairan, hal yang penting untuk diketahui tidak hanya perkembangan perikanannya tetapi juga ketersediaan stok dan informasi lain yang berkaitan dengan karaktertistik populasi sumber daya ikan, upaya pemanfaatan dan keberlanjutan sistem usaha serta 
pengelolaan sumber daya ikan yang tersedia.

Perairan Barru yang terletak di Selat Makassar bagian selatan pada umumnya terdiri atas laut dalam yang mendapat pengaruh arus laut bebas. Daerah tersebut memiliki produktivitas yang tinggi, mengingat proses up welling sering terjadi di daerah pertemuan arus antara Laut Jawa, Selat Makassar, dan Laut Flores. Dengan kondisi perairan yang subur tersebut dan adanya sumber daya ikan yang sudah dimanfaatkan dapat terlihat produksi perikanan yang cukup tinggi dari perairan Selat Makassar. Data Statistik Perikanan menunjukan bahwa produksi perikanan laut tahun 2005 di Kabupaten Barru sekitar 113.281 ton atau $36,1 \%$ dari total produksi perikanan laut di Provinsi Sulawesi Selatan, sekitar $40,6 \%$ di antaranya merupakan produksi ikan demersal.

Secara garis besar, sumber daya ikan di perairan Barru dapat dibagi menjadi dua kelompok besar, yaitu kelompok ikan pelagis dan sumber daya ikan demersal. Sumber daya ikan demersal yang penting di perairan Barru adalah ikan karang ekonomis penting atau yang termasuk kategori food fishes seperti jenis ikan kakap merah, kerapu, dan lencam (Lethrinus spp.). Pada umumnya jenis ikan ini ditangkap oleh para nelayan pancing di sekitar perairan karang atau terumbu karang. Penangkapan ikan karang dengan pancing ulur (hand line) dan rawai dasar (bottom long line) di Selat Makassar bagian selatan antara lain banyak dilakukan di perairan Barru, sekitar Kepulauan Lari-Larian, sekitar Pulau Laut, Pangkajene Kepulauan, dan perairan Takabonerate di Selayar. Belum banyak hasil penelitian tentang perikanan demersal di perairan Selat Makassar, khususnya yang memanfaatkan daerah lereng benua (continental slope) sebagai daerah penangkapannya. Sementara pemanfaatan ikan pelagis kecil utamanya ikan terbang sudah tinggi (Rangka \& Ratnawati, 2005). Sumber daya ikan kakap merah dan kerapu merupakan komoditas perairan karang yang paling banyak diusahakan di Sulawesi Selatan. Produksi ikan kerapu antara tahun 1998-2004 naik rata-rata 7,9\% setiap tahunnya. Pada tahun 2004 produksi ikan kerapu tersebut sekitar 34\% dari produksi total ikan kerapu di seluruh Indonesia (Dinas Kelautan dan Perikanan Provinsi Sulawesi Selatan, 1999-2005). Penelitian ini tentang aspek penangkapan dan biologi sumber daya ikan kakap merah dan kerapu di perairan Barru, Sulawesi Selatan dibahas secara ringkas dalam tulisan ini.

\section{DESKRIPSI UMUM LOKASI PENELITIAN}

Secara geografis, Sulawesi Selatan terletak di antara $03-60^{\circ}$ Lintang Selatan dan $118-122^{\circ}$ Bujur Timur, mempunyai wilayah perairan seluas kurang lebih $262.887 \mathrm{~km}^{2}$ dengan panjang garis pantai $2.500 \mathrm{~km}^{2}$. (Dinas Kelautan dan Perikanan Provinsi Sulawesi Selatan, 2005). Perairan Selat Makassar bagian selatan memiliki daerah lereng benua (continental slope). Daerah perairan dangkal (shelf area) pada kedalaman kurang dari $60 \mathrm{~m}$ tidak begitu luas, karena merupakan bagian dari laut dalam yang membentang dari Mindanau, masuk ke Selat Makassar dan bersatu dengan Laut Flores di selatan yang memiliki kedalaman lebih dari $2.000 \mathrm{~m}$. Di daerah ini terdapat gugusan karang di daerah Pangkajene Kepulauan (Pangkep) dan di sekitar Kepulauan Spermonde. Perairan paparan di daerah ini relatif sempit karena terdapat daerah lereng benua yang memanjang dari daerah Kepulauan Spermonde sampai di sebelah Barat Mamuju. Semakin ke utara kedalaman perairan bertambah dengan tajam, membentuk perairan laut dalam dan langsung berhubungan dengan basin Sulawesi dan basin Makassar di utara 
(Morgan \& Valencia, 1983).

Di Selat Makassar arus laut datang dari utara yaitu dari Laut Sulawesi. Pada musim barat atau barat laut arus khatulistiwa yang kecepatannya dapat mencapai $30-40 \mathrm{~km} /$ jam menuju ke arah selatan dan selanjutnya membelok ke arah timur ke Laut Flores. Pada musim tenggara atau timur kecepatan arus dari utara lebih lambat dan setelah sampai di bagian selatan membelok ke arah barat dan masuk ke Laut Jawa (Wyrtki, 1961). Musim tenggara berlangsung antara bulan Agustus sampai Maret dan merupakan musim penangkapan ikan bagi nelayan di daerah Pinrang, Pare-pare, Barru, Pangkep, sampai daerah Takalar di selatan.

\section{ALAT TANGKAP}

Alat tangkap yang digunakan oleh nelayan di daerah Barru untuk menangkap ikan dasar adalah rawai dasar, pancing ulur, dan jaring insang dasar.

\section{Rawai Dasar (Bottom Long Line)}

Deskripsi satu pis (tinting) rawai dasar terdiri atas 600 mata pancing dilengkapi dengan dua buah pemberat batu (masingmasing $3 \mathrm{~kg}$ ), pada setiap ujung tali utamanya. Tali utama (main line) sepanjang $3.000 \mathrm{~m}$ terbuat dari bahan nilon nomor 1.500 dan tali cabang (branch line) terbuat dari senar nomor 5.000. Jarak antar tali cabang $7,5 \mathrm{~m}$. Satu tali cabang mempunyai 1-2 mata pancing (nomor 7 atau 8) pada bagian ujungnya (Gambar 1).

Umpan yang digunakan adalah ikan hasil tangkapan pancing ulur atau jaring yang digunakan saat bersamaan. Pancing yang telah diturunkan (setting) ditinggalkan selama satu atau dua malam. Pada saat jeda menggunakan pancing ulur atau jaring insang dasar. Perahu yang digunakan jenis

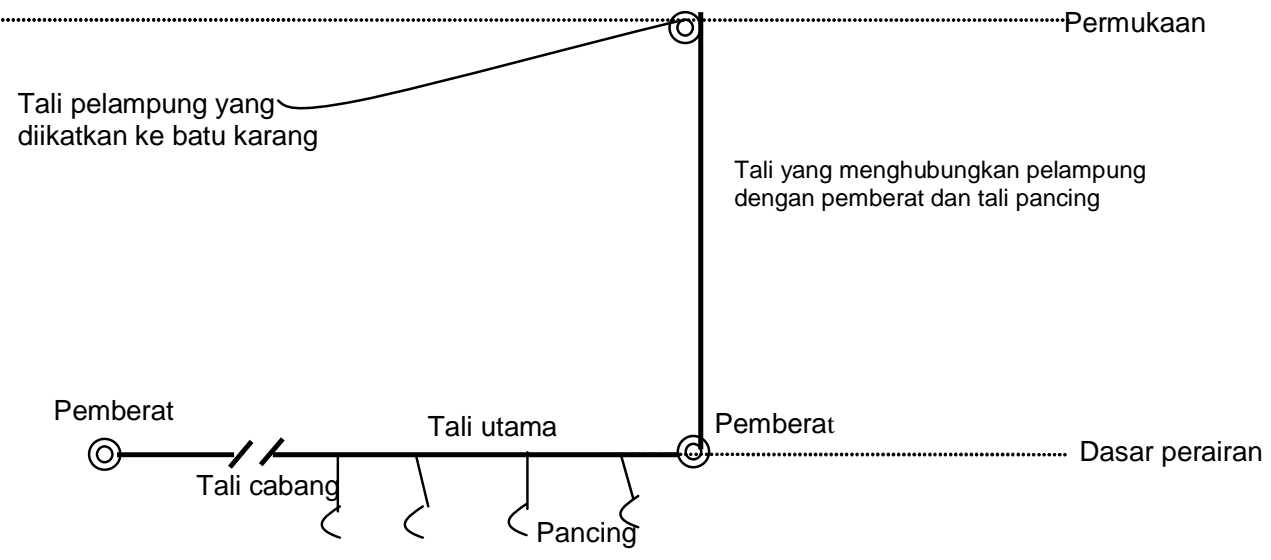

Gambar 1. Konstruksi rawai dasar di perairan Barru.

Figure 1. Construction of bottom long line in the waters of Barru.

Keterangan/Remarks: Mata pancing nomor 7 atau 8, jumlah antara 400-600 buah; tali utama (main line) berupa nylon nomor 1.500; tali cabang (branch line) berupa senar nomor 5.000 sepanjang $4 \mathrm{~m}$; jarak antar tali cabang $7 \mathrm{~m}$ 
jukung berukuran panjang $9 \mathrm{~m}$; lebar 1,2 $\mathrm{m}$; dan dalam $0,8 \mathrm{~m}$ dengan kekuatan mesin 12 DK. Dalam pengoperasiannya perlu dipilih dasar perairan yang agak rata meskipun penangkapannya berdekatan dengan daerah karang. Pemilihan lokasi ini menggunakan peta atau kadang-kadang sudah ada yang membawa kompas dan global positioning system portabel.

\section{Pancing Ulur (Hand Line)}

Pacing ulur mempunyai panjang tali utama yang bervariasi, disesuaikan menurut kedalaman perairan. Terdapat 3-4 tali cabang yang mempunyai pancing antara 3-5 buah (nomor 6 atau 7) pada bagian ujungnya. Panjang tali cabang $40 \mathrm{~cm}$ dengan jarak antar tali cabang $1 \mathrm{~m}$ (Gambar 2). Alat tangkap ini dioperasikan bersamaan dengan rawai dasar atau sendiri-sendiri.

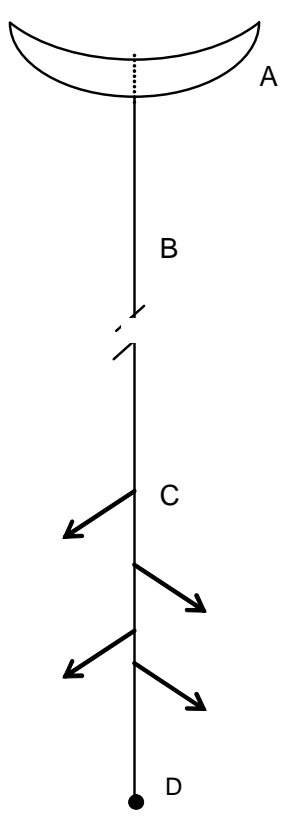

Gambar 2.

Figure 2.
Keterangan/Remarks:

A. Perahu kayu, 12 DK

B. Tali utama (main line)

Panjang: disesuaikan menurut kedalaman perairan

Bahan: senar monofilamen nomor 25-30

C. Tali pancing (branch line)

Panjang: $40 \mathrm{~cm}$

Bahan: senar monofilament nomor 15

Pancing: nomor 7, jumlah antara 3-5 buah Jarak antar tali pancing $1 \mathrm{~m}$

D. Pemberat: besi 100-200 g.

\section{Jaring Insang Dasar (Bottom Gill Net)}

Jaring insang dasar untuk menangkap ikan demersal mempunyai bahan dasar dari senar nomor 500 dengan mesh size 4 inci. Panjang 1 pis sekitar $40 \mathrm{~m}$ dan dalam $5 \mathrm{~m}$. Jaring dilengkapi dengan dua buah tali ris atas dari poly ethylene berdiameter $4 \mathrm{~mm}$, tanpa tali ris bawah. Pemberat timah 2,5 $\mathrm{kg}$ dan pelampung (54 buah) dari potongan sandal jepit terdapat di tali ris atas (Gambar 3). Satu perahu yang terdiri atas 2-3 anak buah kapal mempunyai 60 pis jaring yang disambung satu dengan lainnya. Satu trip penangkapan berkisar antara 1-3 hari. Penurunan jaring (setting) dilakukan pada sore hari dan diangkat (hauling) pada pagi harinya. 


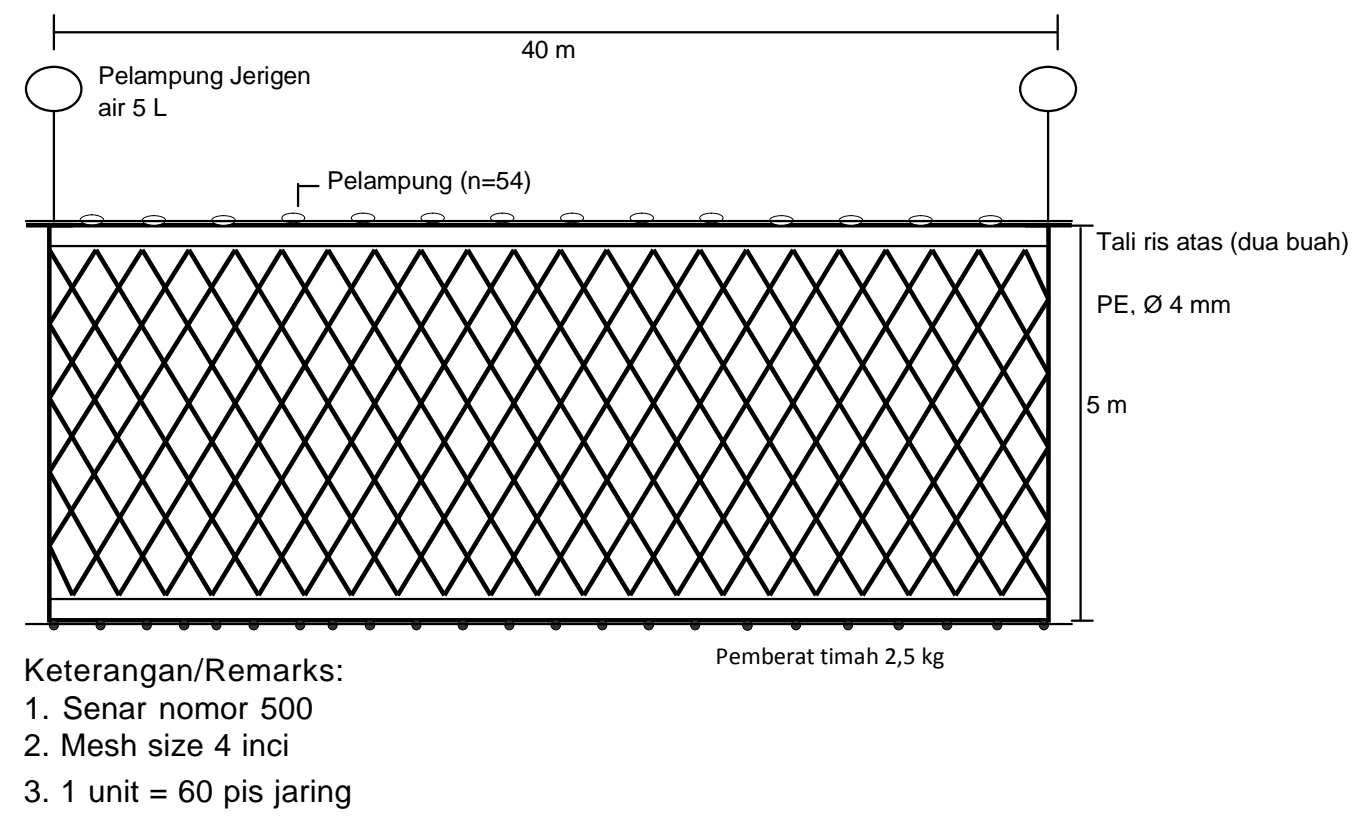

Gambar 3. Konstruksi jaring insang dasar di perairan Barru.

Figure 3. Construction of bottom gill net in the waters of Barru.

\section{DAERAH PENANGKAPAN}

Daerah penangkapan ikan oleh nelayan yang menggunakan pancing ulur dan jaring insang terdapat di perairan yang tidak jauh dari tempat tinggal (pendaratan perahu), sekitar 2-3 jam waktu tempuh ke daerah penangkapan ikan di perairan Barru atau antara 3-4 jam ke perairan Pangkajene Kepulauan. Rawai dasar banyak digunakan di perairan di sekitar Kepulauan Spermonde. Pada musim barat, aktivitas penangkapan ikan berkurang karena ombak relatif tinggi dan kemampuan penangkapan terbatas. Konsentrasi pendaratan ikan demersal hasil pancingan adalah di daerah Ujungbatu, Pancana, Aluppange, dan Polijiwa.

\section{KOMPOSISI JENIS HASIL TANGKAPAN}

Pengamatan pada bulan Agustus dan Oktober tahun 2006 diperoleh komposisi hasil tangkapan rawai dasar didominansi oleh dua famili, yaitu Lutjanidae (ikan kakap) dan Serranidae (ikan kerapu). Jenis ikan dominan pada famili Lutjanidae yaitu Lutjanus malabaricus, Pinjalo pinjalo, dan Lutjanus vittus. Jenis ikan dominan pada famili Serranidae yaitu jenis Epinephelus malabaricus, Epinephelus areolatus, dan Epinephelus maculatus. Selain itu tertangkap juga ikan lentjam (famili Lethrinidae) dan ikan karang (famili Carangidae). Komposisi hasil tangkapan dalam satu trip (dua hari) dijelaskan pada Tabel 1. 
Tabel 1. Komposisi jenis ikan karang ekonomis penting hasil tangkapan rawai dasar di perairan Barru, bulan Agustus dan Oktober 2006

Table 1. Catch composition of economically coral fish species caught by bottom longline in the waters of Barru, August and October 2006

\begin{tabular}{|c|c|c|c|c|c|}
\hline \multirow{2}{*}{ Famili/Spesies (Family/Species) } & \multirow{2}{*}{ Nama lokal/Local name } & \multicolumn{2}{|c|}{ Bulan Agustus } & \multicolumn{2}{|c|}{ Bulan Oktober } \\
\hline & & $(\mathrm{kg})$ & (\%) & $(\mathrm{kg})$ & $(\%)$ \\
\hline \multicolumn{6}{|l|}{ Lutjanidae } \\
\hline Lutjanus malabaricus & Ikan merah & 58,2 & 43,4 & 103,3 & 62,1 \\
\hline Lutjanus hyselopterus & Katamba serang & 1,6 & 1,2 & 7,8 & 4,7 \\
\hline Lutjanus vittus & Mangori & 7,5 & 5,6 & 12,0 & 7,2 \\
\hline Lutjanus sebae & Ikan merah & 3,0 & 2,2 & 0,0 & 0 \\
\hline Pinjalo pinjalo & Dapa & 13,2 & 9,8 & 20,0 & 12,0 \\
\hline Pristipomoides typus & Anggoli & 5,9 & 4,4 & 2,8 & 1,7 \\
\hline \multicolumn{6}{|l|}{ Serranidae } \\
\hline Epinephelus malabaricus & Langgoa, maso & 11,4 & 8,5 & 3,8 & 2,3 \\
\hline Epinephelus areolatus & Langgoa & 1,9 & 1,4 & 5,2 & 3,1 \\
\hline Epinephelus maculatus & Nae & 0,0 & 0 & 3,8 & 2,3 \\
\hline Epinephelus microdon & $\mathrm{Nae}$ & 1,7 & 1,3 & 3,3 & 2,0 \\
\hline Plectropomus maculatus & Sunu & 7,0 & 5,2 & 1,0 & 0,6 \\
\hline Variola albimarginata & $\mathrm{Nae}$ & 5,9 & 4,4 & 0,0 & 0 \\
\hline \multicolumn{6}{|l|}{ Lethrinidae } \\
\hline Lutjanus Ientjan & Katamba kesi & 5,5 & 4,1 & 1,5 & 0,9 \\
\hline Lutjanus elongata & Katamba & 2,4 & 1,8 & 0,0 & 0 \\
\hline Gymnocranius gryseus & Tawe-tawe & 4,4 & 3,3 & 1,8 & 1,1 \\
\hline \multicolumn{6}{|l|}{ Carangidae } \\
\hline Caranx melampygus & ikan kuwe & 2,8 & 2,1 & 0,0 & 0 \\
\hline Carangoides malabaricus & ikan kuwe & 1,7 & 1,3 & 0,0 & 0 \\
\hline Jumlah & & 134,2 & 100 & 166,3 & 100 \\
\hline
\end{tabular}

\section{LAJU TANGKAP}

Dari tiga kali penurunan rawai dasar (setting) diperoleh rata-rata laju tangkap (laju pancing, hook rate) pada bulan Oktober 2006 antara 6-8\% (menangkap antara 6-8 ekor setiap 100 mata pancing). Pada bulan Agustus laju pancingnya relatif rendah yaitu $4-6 \%$. Jenis Lutjanus malabaricus, Lethrinus lencam, dan Epinephelus maculatus merupakan hasil dominan. Salah satu penyebab rendahnya hasil tangkapan ini menurut nelayan diduga karena kondisi perairan ombak relatif tinggi sehingga tidak mencapai daerah penangkapan seperti yang diharapkan, sementara perahu yang digunakan relatif kecil (jukung, 12 DK).
Selain ikan kakap merah dan kerapu tertangkap juga jenis ikan dari famili Lethrinidae dan Carangidae. Berdasarkan atas data Statistik Perikanan Kabupaten Barru tahun 2006 (sampai bulan Juli) diperoleh hasil tangkapan jenis ikan tersebut di atas berbeda. Dengan demikian rawai dasar (rawai tetap, bottom long line) merupakan alat tangkap yang lebih efektif dibandingkan pancing ulur dan jaring insang dasar. Hal ini ditunjukan oleh banyaknya hasil tangkapan rawai dasar untuk keempat jenis ikan karang di perairan Barru diikuti oleh pancing ulur. Sementara jaring insang dasar lebih banyak menangkap ikan kuwe (Caranx spp. dan Carangoides spp.) (Gambar 4). 


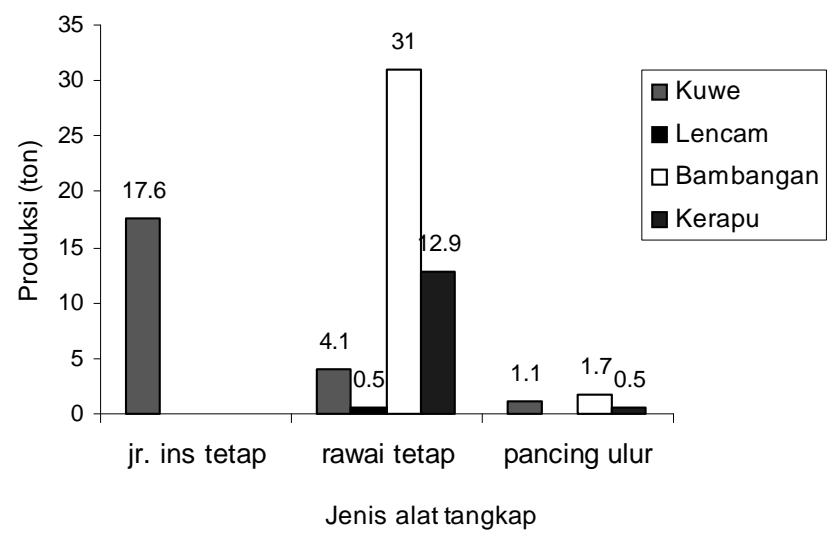

Gambar 4. Komposisi hasil tangkapan ikan karang ekonomis penting menurut jenis alat tangkap di perairan Barru, bulan Juli 2006.

Figure 4. Catch composition of commercially important coral fish by fishing gear used in the waters of Barru, July 2006.

Hasil tangkapan tertinggi antara bulan Januari sampai Juli 2006 untuk ikan kuwe terdapat pada alat tangkap jaring insang tetap 17,6 ton, diikuti rawai dasar 4,1 ton dan pancing ulur 1,1 ton (Dinas Perikanan dan Kelautan Kabupaten Barru, 2006).

\section{KOMPOSISI UKURAN}

Pengukuran frekuensi panjang ikan dilakukan terhadap dua jenis ikan yang dominan didaratkan di TPI Ujungbatu, Barru, yaitu ikan kakap merah dan kerapu. Pada bulan Oktober 2006 diperoleh contoh ikan kakap merah 150 ekor dan ikan kerapu 75 ekor. Hasil pengukuran panjang dan bobot individu contoh ikan dijelaskan pada Tabel 2.

Hubungan panjang dan bobot ikan kakap merah dan kerapu bersifat allometrik positif (nilai $b>3$ ) di mana pertambahan panjang ikan tidak secepat pertambahan bobotnya (Gambar 5 dan 6). Menurut Smith (1991) dalam Nuraini (2007), nilai b yang valid pada ikan kerapu pada umumnya berkisar antara 2,5-3,5. Analisis terhadap lima jenis ikan kerapu di perairan Berau, Kalimantan Timur diperoleh nilai $b$ yang berbeda, berkisar antara $b=2,4881$ sampai $b=3,5.129$. 
Tabel 2. Panjang dan bobot individu ikan Lutjanus malabaricus dan Epinephelus malabaricus yang didaratkan di Barru, bulan Oktober 2006

Table 2. Individual length and weight of Lutjanus malabaricus and Epinephelus malabaricus landed at Barru, Oktober 2006

\begin{tabular}{lcc}
\hline Parameter/Parameters & $\begin{array}{c}\text { Ikan kakap merah } \\
\text { (Lutjanus malabaricus) }\end{array}$ & $\begin{array}{c}\text { Ikan kerapu } \\
\text { (Epinephelus malabaricus) }\end{array}$ \\
\hline Panjang total & & \\
Minimum (cm) & 33,0 & 39,0 \\
Maksimum (cm) & 70,0 & 72,0 \\
Rata-rata (cm) & 48,11 & 56,34 \\
Simpangan baku & 7,92 & 6,96 \\
Bobot & & \\
Minimum (g) & 400 & 800 \\
Maksimum (g) & 4.900 & 4.500 \\
Rata-rata (g) & 1.800 & 2.120 \\
Simpangan baku & 0,81 & 0,81 \\
\hline
\end{tabular}

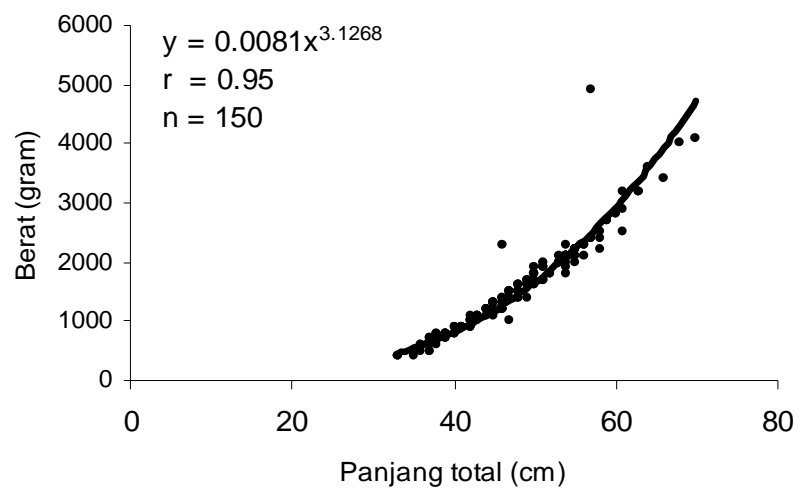

Gambar 5. Grafik hubungan panjang dan bobot ikan kakap merah yang didaratkan di Barru, bulan Oktober 2006.

Figure 5. $\quad$ Length and weight relationship of Lutjanus malabaricus landed at Barru, October 2006. 


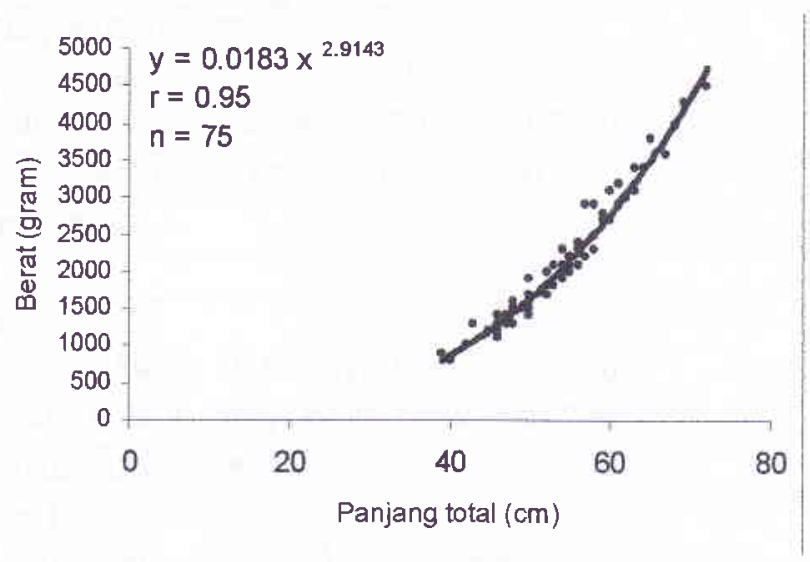

Gambar 6. Grafik hubungan panjang dan bobot ikan kerapu yang didaratkan di Barru, bulan Oktober 2006.

Figure 6. Length and weight relationship of Epinephelus malabaricus landed at Barru, October 2006.

Contoh ikan kakap merah yang tertangkap rawai dasar di perairan Barru diperoleh modus tertinggi pada ukuran panjang total $48 \mathrm{~cm}$, sedangkan ikan kerapu modus tertinggi terdapat pada panjang total $56 \mathrm{~cm}$ (Gambar 7 dan 8). Rata-rata ukuran ikan kerapu lebih besar daripada kakap merah. Beberapa ikan berukuran besar ini dapat diindikasikan sebagai induk walaupun ikan-ikan yang tertangkap tidak berada pada tingkatan matang gonad.

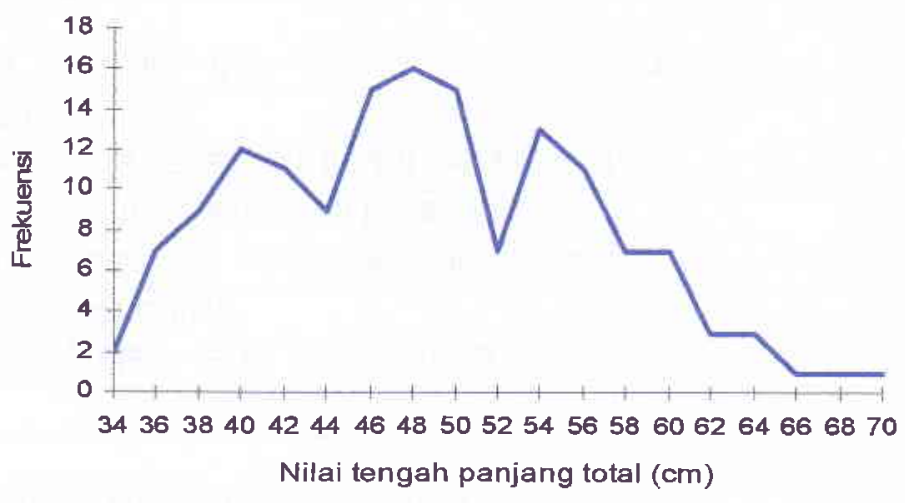

Gambar 7. Sebaran ukuran ikan kakap merah hasil tangkapan rawai dasar di perairan Barru, bulan Oktober 2006.

Figure 7. Length frequency distribution of Lutjanus malabaricus caught by bottom long line in the waters of Barru, October 2006. 


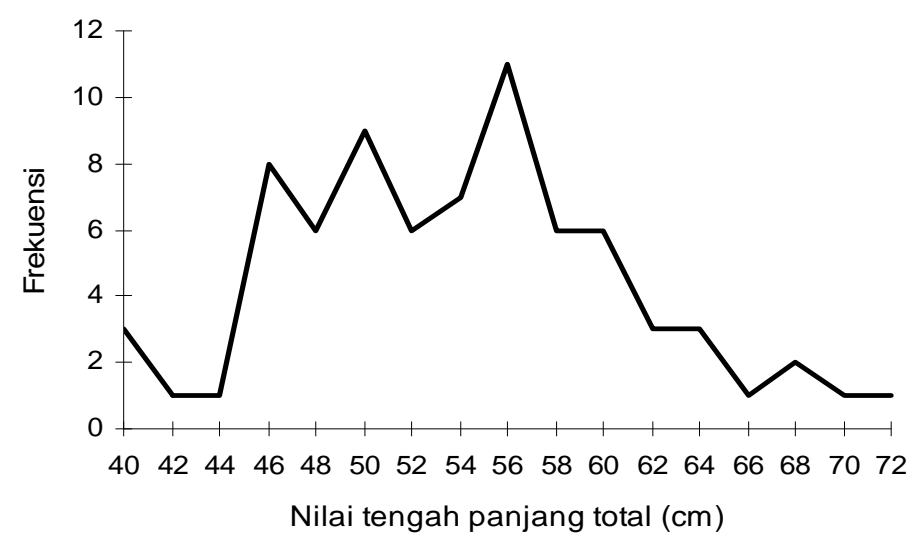

Gambar 8. Sebaran ukuran ikan kerapu hasil tangkapan rawai dasar di perairan barru, bulan Oktober 2006.

Figure 8. Length frequency distribution of Epinephelus malabaricus caught by bottom long line in the waters of Barru, October 2006.

Banyaknya jumlah ikan berukuran besar yang tertangkap dapat merupakan salah satu sumber induk yang mempunyai prospek baik untuk pengembangan usaha budi daya ikan. Sebagaimana dimaklumi bahwa kegiatan penangkapan yang lebih bersifat berburu (hunting) pada suatu saat akan mencapai kejenuhan di mana ukuran ikan yang tertangkap akan semakin kecil.

Penangkapan ikan dengan rawai dasar (bottom long line) lebih selektif dan dapat diadopsi sebagai alat tangkap yang ramah lingkungan dan bertanggungjawab sesuai prinsip-prinsip dalam Code of Conduct for Responsible Fisheries (Food and Agriculture Organization, 1995). Pengamatan ikan kakap merah di Selat Sape (Nusa Tenggara Timur) diperoleh pada panjang total $38 \mathrm{~cm}$ sudah menunjukan stadia matang gonad, sedangkan di perairan Kupang pada panjang total $34,5 \mathrm{~cm}$ (Sumiono, 2000). Pertama kali matang gonad Lutjanus sanguineus di Laut Jawa diperoleh pada panjang total $55 \mathrm{~cm}$ (Karyaningsih \& Suhendrata, 1992). Ikan kakap merah jenis Lutjanus erythropterus di perairan Great Barrier Reef Australia pada panjang total $52 \mathrm{~cm}$ menunjukan sudah matang gonad (McPherson \& Squire, 1992).

\section{KESIMPULAN}

1. Perahu atau kapal yang berbasis di Barru, Sulawesi Selatan memiliki daerah penangkapan ikan demersal khususnya jenis ikan karang ekonomis penting dengan rawai dasar, pancing ulur, dan jaring insang dasar.

2. Daerah penangkapan ikan kakap merah dan kerapu terdapat di perairan Barru dan sekitar Pangkajene Kepulauan dengan kedalaman mencapai $150 \mathrm{~m}$. Pada perairan relatif dangkal $(<50 \mathrm{~m})$ banyak digunakan pancing ulur dan jaring insang dasar.

3. Komposisi hasil tangkapan rawai dasar didominansi oleh jenis ikan dari famili Lutjanidae dan Serranidae. Rata-rata laju pancing (hook rate) rawai dasar antara 4-6 ekor setiap 100 mata pancing (bulan Agustus 2006) dan antara 6-8 setiap 100 mata pancing (bulan Oktober 2006). 
4. Pertumbuhan ikan kakap merah dan kerapu bersifat allometrik positif.

5. Rata-rata ukuran ikan yang tertangkap pada bulan Oktober 2006 berukuran besar dan diindikasikan berukuran induk.

\section{DAFTAR PUSTAKA}

Dinas Kelautan dan Perikanan Provinsi Sulawesi Selatan. 2005. Laporan Tahunan Dinas Kelautan dan Perikanan Tahun 2005.

Dinas Kelautan dan Perikanan Provinsi Sulawesi Selatan. 1999-2005. Statistik Perikanan Provinsi Sulawesi Selatan Tahun 1998-2004. Diterbitkan Setiap Tahun.

Dinas Perikanan dan Kelautan Kabupaten Barru. 2006. Laporan Statistik Perikanan Triwulan I dan II.

Food and Agriculture Organization. 1995. Code of Conduct for Responsible Fihseries. Food and Agriculture Organization-UN. 41 pp.

Karyaningsih, S. \& T. Suhendrata. 1992. Pendugaan ukuran pertama kali matang gonad ikan kakap merah (Lutjanus sanguineus) di Laut Jawa. Jurnal Penelitian Perikanan Laut. 75: 29-32.

McPherson, G. R. \& I. Squire. 1992. Reproduction of three dominant Lutjanus species of the Great Barrier Reef. Inter reef fishery. Asian Fisheries Science. 5: 25-36.
Morgan, J. R. \& M. J. Valencia. 1983. The natural environmental setting In Morgan, J. R. \& M. J. Valencia (Eds.). Atlas for Marine Policy in Southeast Asian Seas. University of California Press. Berkeley. Los Angeles. London. 4-17.

Nuraini, S. 2007. Jenis ikan kerapu (Serranidae) dan hubungan panjang dan bobot di perairan Berrau, Kalimantan Timur. Jurnal Iktiologi Indonesia. 7 (2): 61-65.

Rangka, N. A. \& E. Ratnawati. 2005. Efesiensi usaha penangkapan dan pemasaran ikan terbang di Sulawesi Selatan (Studi kasus nelayan patorani di Kabupaten Polmas, Majene, dan Mamuju, Sulawesi Selatan. Laporan Lokakarya Perikanan Ikan Terbang. Makassar.

Saouma, E. 1986. Strategy for Fisheries Management and Development. Food and Agriculture Organization. Rome. Italy. 25 pp.

Sumiono, B. 2000. Activities of the observer programme. Makalah disajikan pada $1^{\text {st }}$ Technical Coordination Meeting. Cleveland. Australia. November 2000. (Tidak Dipublikasikan).

Wyrtki, K. 1961. Physical oceanography of the Southeast Asian waters. Naga Report. Vol.2. Scripps Inst. of Oce. Univ. of California. 